\title{
Pliocene and Quaternary Deposits in the Northern Part of the San Juan Basin in Southwestern Colorado and Northwestern New Mexico
}

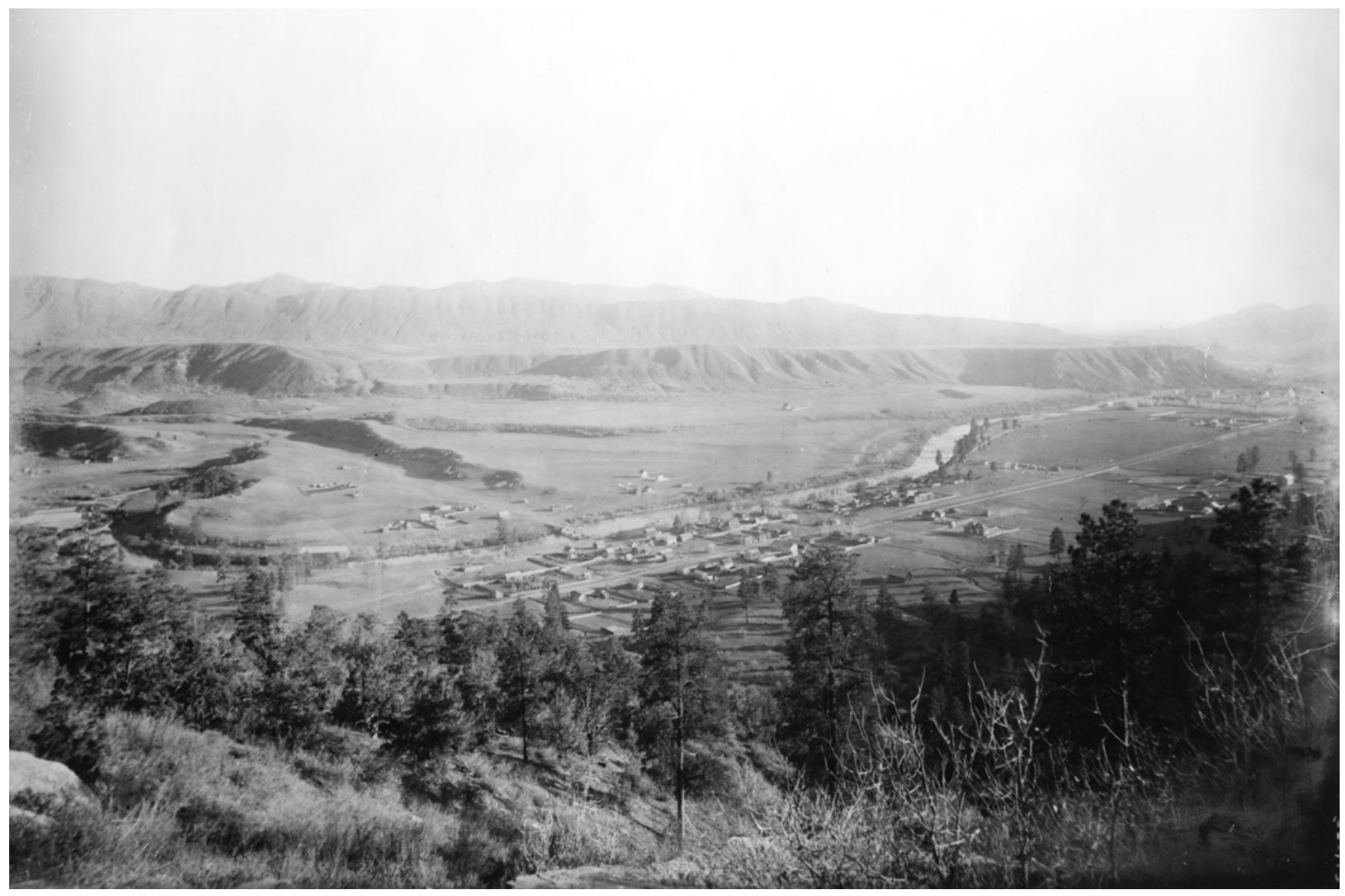

Scientific Investigations Report 2007-5006 


\section{Pliocene and Quaternary Deposits in the Northern Part of the San Juan Basin in Southwestern Colorado and Northwestern New Mexico}




\section{Frontispiece}
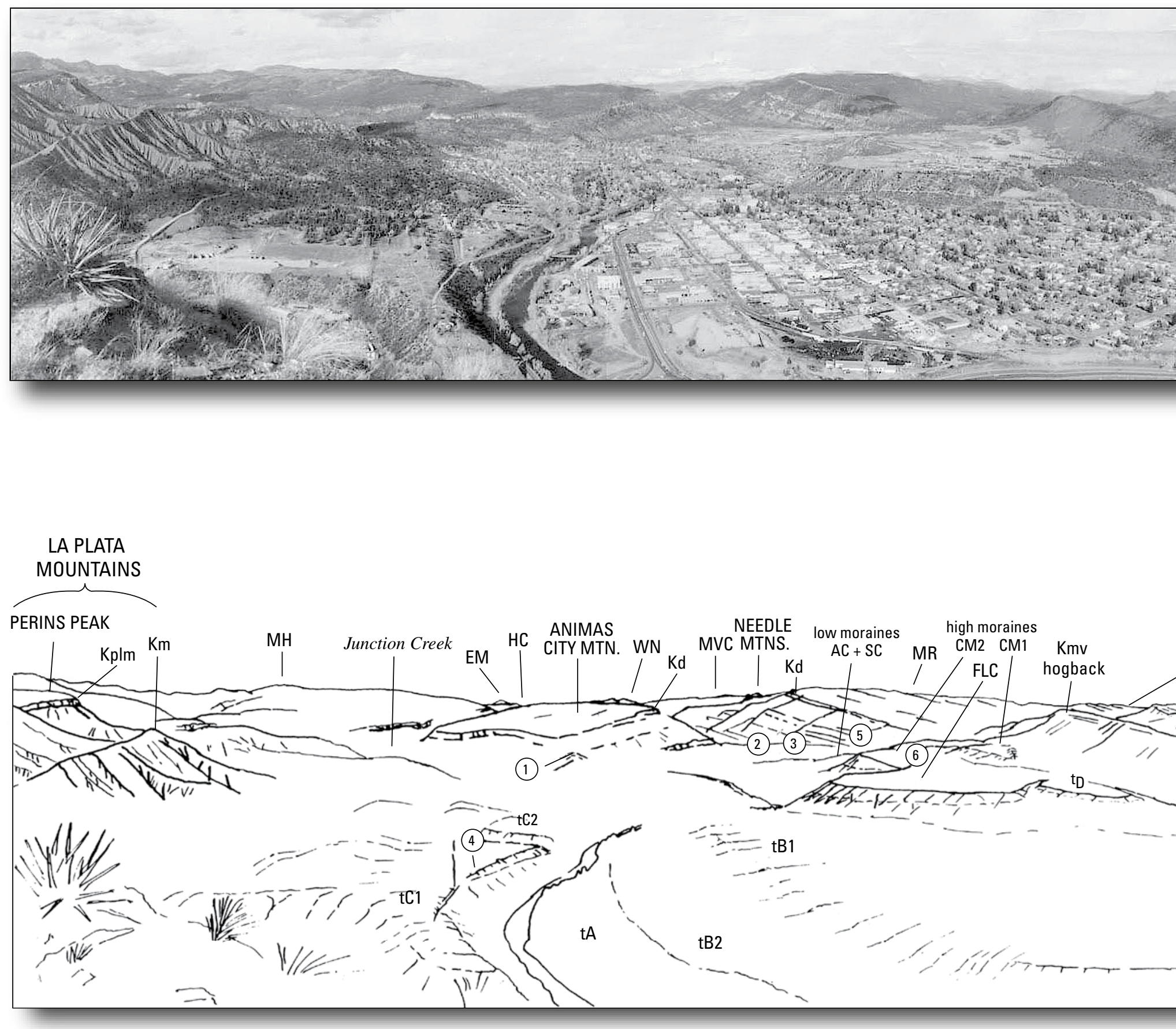

The Animas River Valley near Durango is the north part of the San Juan Basin. Surficial deposits discussed in this report are chiefly in this valley. Left center skyline is north, toward the Needle Mountains, the most uplifted part of the San Juan Mountains and the source of the longest valley glaciers in the Rocky Mountains. Glaciers advanced southward to Durango at least six times, producing a series of end moraines there. Above the river at center and extending right (south) are flat surfaces at several levels. These terraces were cut by the river in soft shale and are armored by rounded clasts of hard bedrock lithologies from the Needle Mountains. Such deposits beneath terraces $360 \mathrm{ft}(110 \mathrm{~m})$ or less above the river begin at the south edge of a glacial moraine and thus are outwash gravel. Gravel capping terraces higher than $360 \mathrm{ft}(110 \mathrm{~m})$ above the river do not begin at a moraine, although some may have begun at moraines that were removed by erosion. Discontinuous remnants of hard gravel cap benches and a few high hills along the valley as far south as Farmington, New Mexico, and beyond. 


\section{San Juan Basin}

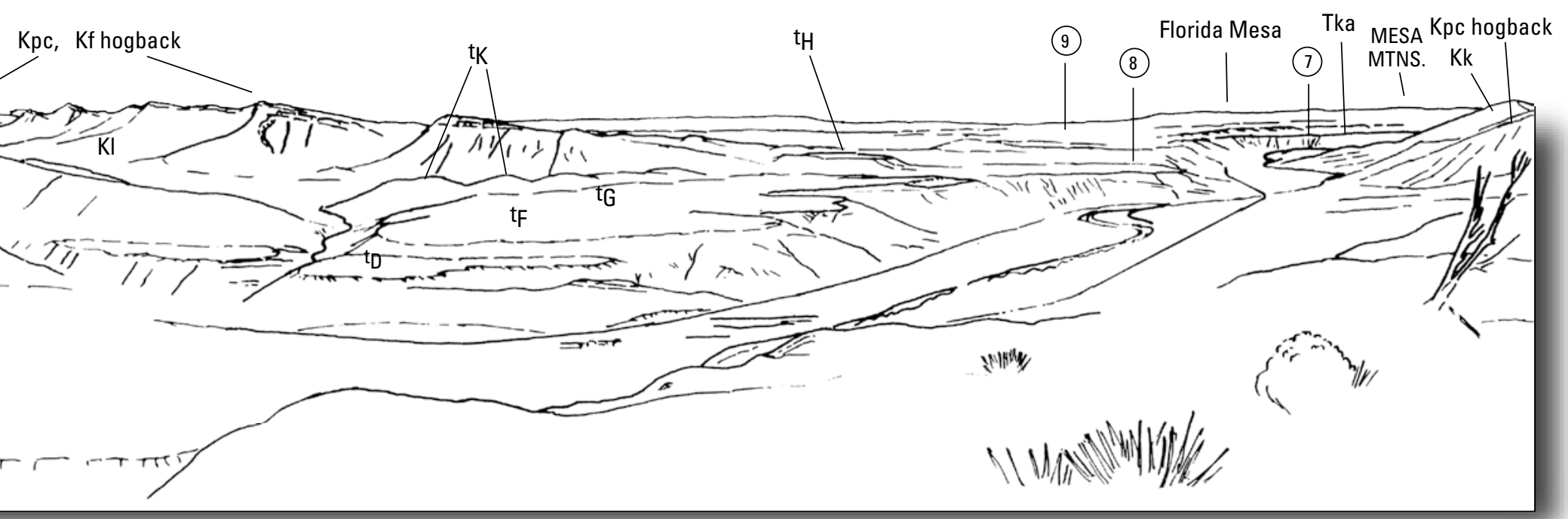

Landmarks shown: EM—Engineer Mountain; HC—Hermosa Creek; WN—West Needle Mountain; AC—Animas City moraines; SC—Spring Creek moraines; FLC—Fort Lewis College; Stratified rock units (older to younger): Jm—Morrison Formation; Kd—Dakota Sandstone; Km—Mancos Shale; Kplm—Point Lookout Sandstone of Mesaverde Group; Kmv—Mesa Verde Group; Kl—Lewis Shale; Kpc—Pictured Cliffs Sandstone; Kf—Fruitland Formation; Kk—Kirtland Shale; Tka—Animas Formation.

Terrace alluvium: 1-Flood plain or low terraces; 2-Upper Animas City outwash; 3-Lower Animas City outwash; 4-Upper Spring Creek outwash; 5-Lower Spring Creek outwash; 6-Upper Durango outwash; 7—Lower Durango outwash; 8-Alluvium; 9-Florida Gravel; 10-Pediment gravel. 


\section{Pliocene and Quaternary Deposits in the Northern Part of the San Juan Basin in Southwestern Colorado and Northwestern New Mexico}

By Glenn R. Scott and David W. Moore

Scientific Investigations Report 2007-5006 


\title{
U.S. Department of the Interior DIRK KEMPTHORNE, Secretary
}

\author{
U.S. Geological Survey \\ Mark D. Myers, Director
}

\section{U.S. Geological Survey, Reston, Virginia: 2007}

For product and ordering information:

World Wide Web: http://www.usgs.gov/pubprod

Telephone: 1-888-ASK-USGS

For more information on the USGS--the Federal source for science about the Earth, its natural and living resources, natural hazards, and the environment:

World Wide Web: http://www.usgs.gov

Telephone: 1-888-ASK-USGS

Any use of trade, product, or firm names is for descriptive purposes only and does not imply endorsement by the U.S. Government.

Although this report is in the public domain, permission must be secured from the individual copyright owners to reproduce any copyrighted materials contained within this report.

Suggested citation:

Scott, G.R., and Moore, D.W., 2007, Pliocene and Quaternary deposits in the northern part of the San Juan Basin in southwestern Colorado and northwestern New Mexico: U.S. Geological Survey Scientific Investigations Report 2007-5006, $13 \mathrm{p}$. 


\section{Contents}

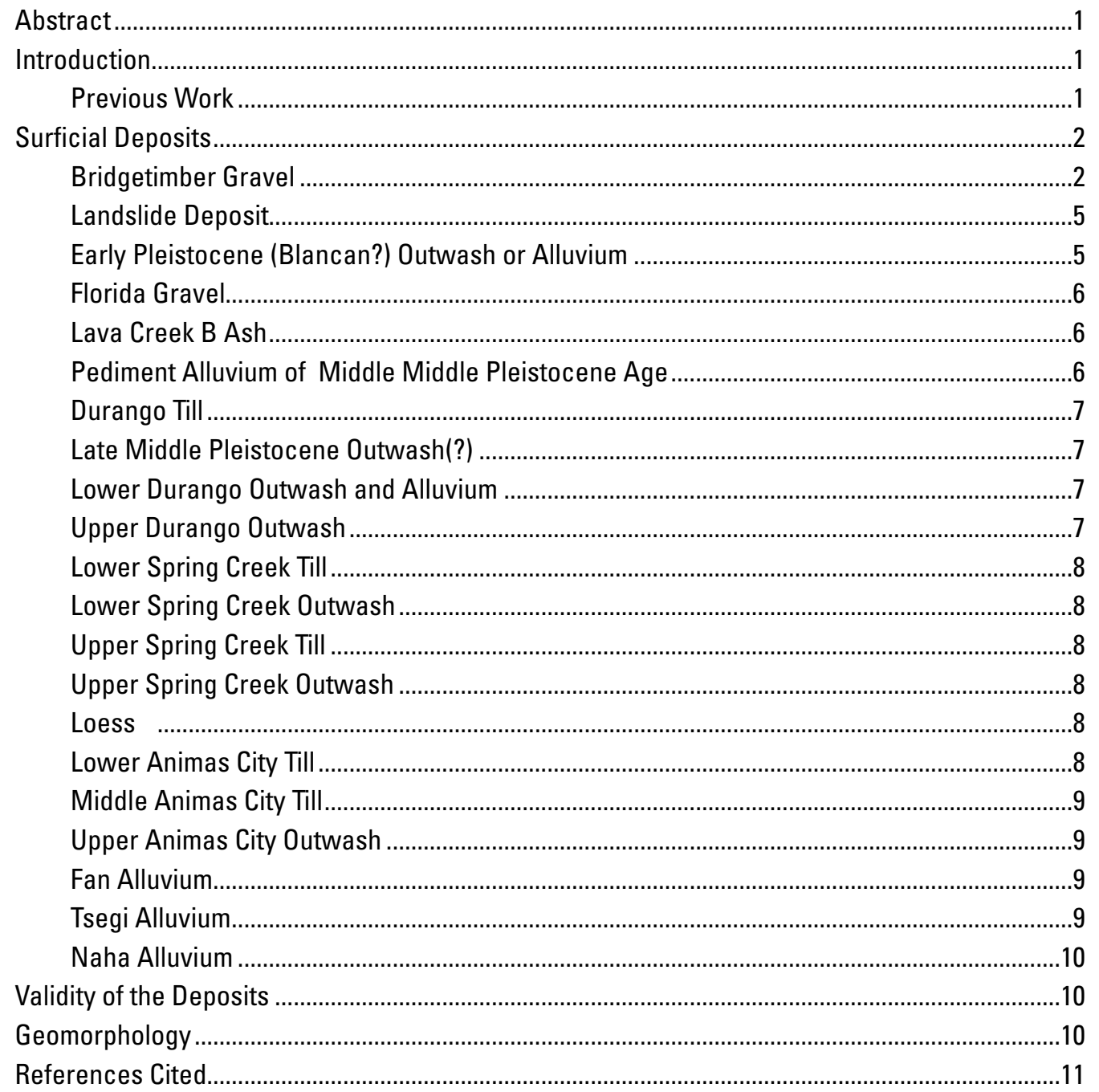

\section{Figure}

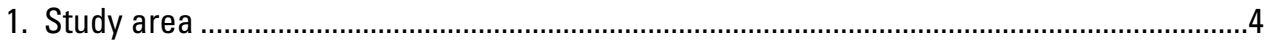

\section{Table}

1. Generalized stratigraphic section in the northwestern part of the San Juan Basin ........3 


\title{
Pliocene and Quaternary Deposits in the Northern Part of the San Juan Basin in Southwestern Colorado and Northwestern New Mexico
}

\author{
By Glenn R. Scott and David W. Moore
}

\section{Abstract}

Unconsolidated late Cenozoic deposits in the northern part of the San Juan Basin range in age from late Pliocene to Holocene. Most of the deposits are alluvial gravel composed of resistant quartzite, sandstone, and igneous, metamorphic, and volcanic rocks derived from the uplifted central core of the San Juan Mountains 20-50 miles (32-80 kilometers) north of the basin. Alluvial deposits are most voluminous in the Animas Valley, but deposits of gravel of the same general age are present in the La Plata, Florida, Los Pinos, and Piedra River valleys as well. Alluvial gravel forms tabular deposits, generally about 20 feet ( 6 meters) thick, that are exposed beneath a sequence of terraces at many levels above the rivers. Gravel layers 360 feet (110 meters) or less above the Animas River are glacial outwash. The gravel layers begin at the south toes of end moraines and extend discontinuously downvalley at least 10-20 miles (16-32 kilometers). Farther south, distinction between outwash and nonglacial alluvium is problematical. Alluvial gravel beneath higher terraces does not grade to end moraines.

Glacial till forms a series of end moraines at the north edge of the town of Durango. The oldest moraines are farthest downvalley, are higher above the river, and have more mature surficial soils than do moraines farther north. The two youngest moraines, the Animas City moraines, are interpreted to be Pinedale in age. They have narrow, ridgelike crests and form nearly unbroken arcs across the valley floor. Small segments of still more weathered moraines, the Spring Creek moraines, are 170-230 feet (52-70 meters) above the river and are 660-990 feet (200-300 meters) farther downvalley. The oldest moraines, the Durango moraines, are on the north end of the unnamed mesa on which Fort Lewis College is located. The base is about 180 feet ( 55 meters) above the river. These oldest moraines may be of Bull Lake age.

Alluvial fans, pediment gravel, and landslides are scattered at several levels in various valleys within the northern San Juan Basin. Except where the Lava Creek B volcanic ash (0.639 mega-annum) is interbedded in them, these crudely bedded accumulations of sandy or clayey material washed from side drainages and added little to our reconnaissance stratigraphic study. Scattered landslide deposits consist of unsorted, mixed soil and fragments of rock.

Loess and local silty and clayey sheetwash alluvium 6-12 feet (2-4 meters) thick form a veneer on low terraces. On higher terraces, such as Red Mesa east of the La Plata River and Florida Mesa east of the Animas River, loess and sheetwash alluvium generally are about 20 feet ( 6 meters) thick but can be as thick as 40-50 feet (12-15 meters) in places on Florida Mesa.

When using the Lava Creek B volcanic ash as a time datum, apparently the timing of late Cenozoic continental deposition in the region was broadly similar to that in the Denver Basin-Front Range region and some other glaciated mountain ranges in the Rocky Mountains. A more accurate dating of Quaternary alluviation must await a thorough dating of the deposits. Thick, extensive outwash gravel indicates enhanced deposition during glacial epochs.

\section{Introduction}

Pliocene and Quaternary deposits were studied near Durango, Colorado, in April and May of 1977, in company at different times with Donald A. Coates, John D. Strobell, and Juanita M. Scott. As a result of reconnaissance mapping, study of soils, geomorphic and stratigraphic positions of deposits, measurement of stratigraphic sections, pebble counts, and collection of volcanic ash beds (later identification by Glen A. Izett), a sequence of deposits was established. This sequence includes alluvial, loess, eolian sand, landslide, till, and outwash deposits ranging in age from Pliocene (Blancan) to latest Holocene. The terms Bull Lake and Pinedale are used here in a general time sense and are not intended to imply exact contemporaneity or correlation with Bull Lake and Pinedale deposits in the type areas in Wyoming.

\section{Previous Work}

The Quaternary deposits in southwestern Colorado and northwestern New Mexico areas were studied by Atwood (1911), Atwood and Mather (1912, 1932), Dickinson (1965), 
Richmond (1965), Bandoian (1969), Pastuszak (1968), and Gillam (1982). Studies using modern techniques to determine the ages and correlations of the deposits had not been done prior to this study. Therefore, as a result of using the methods in this study, even though it was a reconnaissance investigation, the deposits here are arranged in a different sequence than proposed by previous workers. Some previously named deposits are lag gravel, and they have little or no significance as part of a geomorphic sequence. Those names are not used here. In addition, different ages are assigned herein to some deposits, and some deposits are placed in different map units.

Ages of deposits are not closely controlled by radiometric dating methods. The ages are inferred from height of deposits above rivers and from relative dating methods that involve soil and weathering development. The youngest glacial till is assumed to be middle Pinedale in age, and successively older tills follow the order of glaciations used by most workers in the Rocky Mountains.

\section{Surficial Deposits}

Most of the stream deposits in the northern San Juan Basin area are composed of glacial outwash. Eleven terrace surfaces have been recognized, ranging from $1,200 \mathrm{ft}$ (366 m) to about $10 \mathrm{ft}(3 \mathrm{~m})$ above the present Animas River. Apparently the deposits beneath the oldest terrace surface and beneath the two youngest terrace surfaces are nonglacial alluvium. All of the others probably are outwash from glaciers near Durango during several glacial stages in the Quaternary. At least five terminal moraines and possibly one additional older end moraine were recognized. The youngest moraines form nearly continuous curving ridges that loop across the flat-floored broad valley of the Animas River near the northern edge of Durango. Upstream from the moraines is a typical U-shaped valley containing ground moraine and outwash. Because of stream abrasion, the less-resistant rock types become more scarce, and surface diameters of all clasts decrease downstream.

The wind has eroded bedrock and alluvium and deposited loess and eolian sand on upland areas. The loess overlies much of the northern part of the San Juan Basin, where it possibly forms several sheets that we estimate to range in age from about 300,000 to 50,000 years. The loess is some of the best grazing and cropland on the uplands. Eolian sand covers large parts of the San Juan Basin, where large dunes still are active. Several episodes of sand deposition are inferred to have occurred, ranging from about 25,000 years ago until the present.

Deposits that mantle slopes include sheetwash alluvium, a poorly sorted, crudely stratified material deposited by sheetflow of rainwater or snowmelt, and colluvium, deposited by downslope gravitational movement of material. These deposits generally are thin and of little significance except that they conceal bedrock.
Because of extremely deep incision by the Animas River near Durango (approximately four times as deep as the incision of the South Platte River near Denver, Colorado) and the incompetence of the Cretaceous Mancos Shale, many landslide deposits have formed, some of which are still active.

Table 1 shows the sequence of surficial deposits, heights of alluvial terrace surfaces above major streams, and known or estimated ages.

\section{Bridgetimber Gravel}

One of the oldest and geomorphically highest alluviums in the area is the Bridgetimber Gravel, which caps Bridge Timber Mountain on the divide between the Animas and La Plata Rivers approximately $10 \mathrm{mi}(16 \mathrm{~km})$ southwest of Durango. The gravel is more than $100 \mathrm{ft}(30 \mathrm{~m})$ thick. The gravel is composed of boulders, cobbles, and pebbles, most of which are deeply weathered and set in a weathered matrix of sand, silt, and clay. In a fresh exposure, the matrix is chiefly composed of very dark colored, completely to partly disintegrated clasts of volcanic and dike rocks, sandstone, and lesser vein quartz and granitic rocks; well-preserved clasts are harder rock types.

The gravel is on a well-formed erosion surface (pediment) on Bridge Timber Mountain approximately 2,100 ft (640 $\mathrm{m}$ ) above the Animas River. This great height above the river led Atwood and Mather (1932) to suggest a Pliocene (?) age for the gravel. Later workers, including Barnes and others (1954), Wanek (1959), Baltz (1967), and Haynes and others, (1972), have assigned a Pliocene or Pleistocene age to the Bridgetimber Gravel and apparently correlative deposits, based partly on the original age assignment and partly on the height above the Animas River. Richmond (1965), on the other hand, tentatively assigned an age of Pleistocene (Washakie Point glaciation) to the gravel.

Based on the compositions of the clasts, we believe that the La Plata River deposited the Bridgetimber Gravel (fig. 1). The composition of the gravel deposited by the Animas River differs from that deposited by the other rivers in the area. The Animas River gravel contains mostly less-resistant rocks but contains a few still-preserved hard rock clasts. In the Animas River, the rock clasts there are chiefly quartzite from the Uncompahgre Formation, various types of porphyry, and lesser amounts of quartz, chert, jasper, sandstone, hornblende gneiss, silicified fault gouge, and several different granitoid plutonic rocks. On Bridge Timber Mountain the gravel is composed of siliceous to intermediate volcanic and dike rocks (about 90 percent), quartzite, rare banded purplish-gray and green argillite(?), and rare sandstone clasts.

As previously stated, comparison of the clasts in the gravel on Bridge Timber Mountain with those deposited by the Animas and La Plata Rivers showed that the Bridgetimber Gravel in the type area was deposited by the La Plata River (a source in the La Plata Mountains also was suggested by Richmond [1965, p. C142]). The gravel in secs. 25 and 36, T. 34 
Table 1. Generalized stratigraphic section in the northwestern part of the San Juan Basin.

\begin{tabular}{|c|c|c|c|c|}
\hline $\begin{array}{l}\text { Known } \\
\text { or } \\
\text { inferred age }\end{array}$ & $\begin{array}{c}\text { Stratigraphic } \\
\text { unit }\end{array}$ & $\begin{array}{l}\text { Height of alluvial or } \\
\text { outwash terrace } \\
\text { above major stream, } \\
\text { (feet and meters) in } \\
\text { Animas River }\end{array}$ & $\begin{array}{l}\text { La Plata } \\
\text { River } \\
\text { (terraces } \\
\text { rise } \\
\text { downstream) }\end{array}$ & $\begin{array}{c}\text { Front } \\
\text { Range } \\
\text { correlative (?) } \\
\text { units }\end{array}$ \\
\hline 10,000 to 0 & $\begin{array}{l}\text { Naha Alluvium } \\
\text { Tsegi Alluvium } \\
\text { Eolian sand }\end{array}$ & & & \\
\hline Pinedale & $\begin{array}{l}\text { Upper Animas City } \\
\text { Middle Animas City till } \\
\text { Lower Animas City till } \\
\text { Lower Animas City outwash } \\
\quad \text { (not discussed in text) }\end{array}$ & $\begin{array}{l}40(12) \text { outwash } \\
60(18)\end{array}$ & $40(12)$ & $\begin{array}{l}\text { Broadway } \\
\text { Alluvium }\end{array}$ \\
\hline \multicolumn{5}{|l|}{79,000} \\
\hline & Loess & & & \\
\hline $\begin{array}{l}\text { Bull Lake } \\
122,000\end{array}$ & $\begin{array}{l}\text { Upper Spring Creek till } \\
\text { Upper Spring Creek outwash } \\
\text { Lower Spring Creek till } \\
\text { Lower Spring Creek outwash }\end{array}$ & $\begin{array}{l}150(45) \\
120(30) \\
80(24) \\
170(43-52) \\
140 \text { in text }\end{array}$ & $160(48)$ & $\begin{array}{l}\text { Louviers } \\
\text { Alluvium }\end{array}$ \\
\hline \multicolumn{5}{|l|}{$\begin{array}{l}\text { Sangamon } \\
\text { interglacial } \\
132,000\end{array}$} \\
\hline $\begin{array}{l}\text { Late middle Sacagawea } \\
\text { Pleistocene Ridge? } \\
(140,000- \\
\text { 302,000)(Wisconsin?) }\end{array}$ & $\begin{array}{l}\text { Loess } \\
\text { Upper Durango Till } \\
\text { Upper Durango outwash } \\
\text { Lower Durango Till } \\
\text { Lower Durango outwash } \\
\text { Alluvium }\end{array}$ & $\begin{array}{l}230-340(70-104 \\
320-360(97-110) \\
420-440(128-134) \\
500(150)\end{array}$ & & $\begin{array}{l}\text { Slocum } \\
\text { Alluvium }\end{array}$ \\
\hline $\begin{array}{l}\text { Middle middle } \\
\text { Pleistocene } \\
\text { interglacial } \\
(639,000)\end{array}$ & $\begin{array}{l}\text { Pediment alluvium } \\
\text { Lava Creek B ash }\end{array}$ & & & $\begin{array}{l}\text { Verdos } \\
\text { Alluvium }\end{array}$ \\
\hline $\begin{array}{l}\text { Early middle } \\
\text { Pleistocene } \\
(610,000-770,000)\end{array}$ & Florida Gravel (outwash?) & $500-640(152-195)$ & & \\
\hline $\begin{array}{l}\text { Early Pleistocene } \\
(1,300,000-1,680,000)\end{array}$ & $\begin{array}{l}\text { Outwash or alluvium } \\
\text { High gravels of Animas } \\
\text { River }\end{array}$ & $\begin{array}{l}840-1,000(256-305 \\
1,150(351)\end{array}$ & & $\begin{array}{l}\text { Rocky Flats } \\
\text { Alluvium }\end{array}$ \\
\hline Quaternary (many ages) & Landslide deposits & & & \\
\hline $\begin{array}{l}\text { Pliocene Blancan?) } \\
\text { (2.5-3 m.y.) }\end{array}$ & $\begin{array}{l}\text { Gravel on Mesa Mountains } \\
\text { Bridgetimber Gravel } \\
\text { (deposit of the La Plata } \\
\text { River) }\end{array}$ & $\begin{array}{l}1,480(451) \\
2,100(640)\end{array}$ & $1,150-1,350-411$ & \\
\hline
\end{tabular}




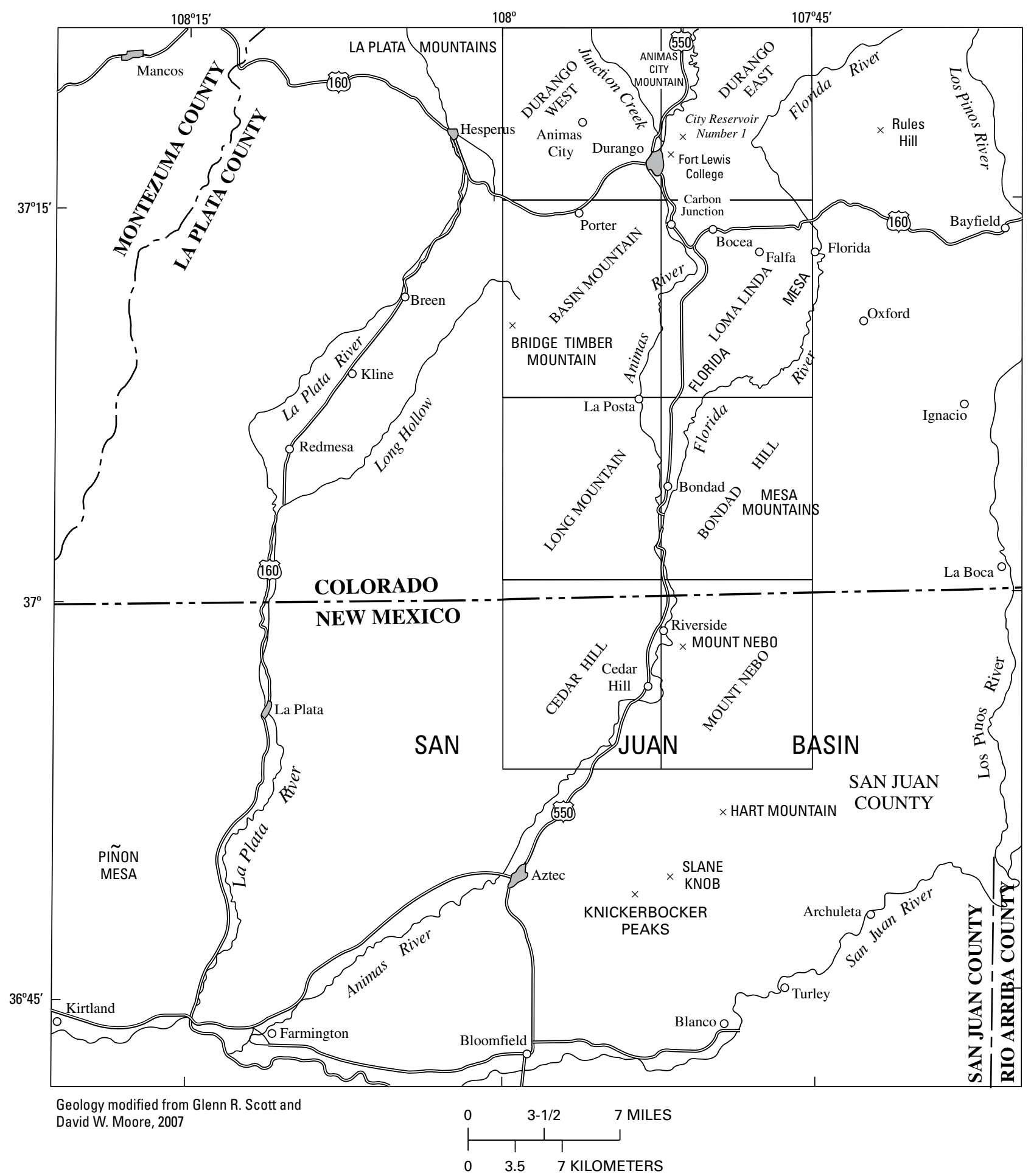

Figure 1. Study area. 
N., R. 11 W., is about $1,150-1,350 \mathrm{ft}(305-411 \mathrm{~m})$ above the La Plata. The divide between the La Plata River and the Animas River that existed during deposition of the Bridgetimber Gravel was destroyed by headward cutting of tributaries of the Animas River. Listed in table 1 are high gravels of the Animas River. Some of those high gravels are discussed in following sections. Other apparently correlative ancient deposits of the Animas River are on Knickerbocker Peaks, in the NW1/4 sec. 16, T. 30 N., R. 10 W., altitude 6,788 ft (2,070 m), Hart Mountain, in secs. 30 and 31, T. 31 N., R. 9 W., altitude 6,943 $\mathrm{ft}(2,116 \mathrm{~m})$, and Slane Knob, in the SE1/4 sec. 10, T. 30 N., R. $10 \mathrm{~W}$., altitude 6,858 ft (2,090 m), southeast of Aztec (fig. 1), where the deposits are about 1,150, 1,150, and 1,220 ft (350, 350 , and $372 \mathrm{~m}$ ), respectively, above the Animas River.

A presumed correlative deposit on Mount Nebo was deposited by the Animas River, about 1,140 ft (348 m) above the Animas. A strongly developed brown soil is present in the upper part of the alluvium on Mount Nebo, altitude 13,205 ft $(4,024 \mathrm{~m})$, in the SW $1 / 4$ sec. 2, T. 39 N., R. 6 W. A reddishbrown $\mathrm{B}$ horizon is well preserved there, overlying a strong $\mathrm{K}$ horizon. The $\mathrm{K}$ horizon shows a 1/8-inch-thick $(3 \mathrm{~mm})$ laminar layer (stage 4 of Gile [1966]); it probably contains about 75-80 percent calcium carbonate (Michael N. Machette, oral commun., 1977). Rinds of calcium carbonate on the bottoms of stones are more than one inch $(2.5 \mathrm{~cm})$ thick.

We consider the Bridgetimber Gravel to be Pliocene (Blancan?, 2.5-3.0 m.y.) in age and possibly the same age as the Nussbaum Alluvium in eastern Colorado and the lower part of the Blanco Formation in Texas. The Pliocene age is assigned because of its great height above the La Plata and Animas Rivers (it is the highest fluvial pediment deposit), because it has reversed remanent magnetism in outcrops in northern New Mexico (J.D. Strobell, Jr., written commun., 1979), and because the rock clasts are so extremely weathered in contrast to clasts in fluvial deposits of early Pleistocene age.

Gravel on Mesa Mountains 14-20 mi (22-32 km) south of Durango and about 7,630 ft (2,325 m) in altitude is perhaps one of the older remaining surficial deposits in the area, but the exact age and origin of the gravel are uncertain. Relative to the Animas River the deposits are lower than the Bridgetimber Gravel, and thus they possibly are younger. They are present as discontinuous, patchy veneers $1-5 \mathrm{ft}(0.3-1.5 \mathrm{~m})$ thick, at a lower altitude, and their basal contact with underlying bedrock rises and falls in unison with the rolling topographic surface. The deposits are interpreted to be lag gravel on a rolling erosional upland surface, with one exception.

The exception is a small $(0.2$ by $0.6 \mathrm{~km})$ deposit of gravel with rounded clasts in $\mathrm{NW}^{1} / 4$, sec. 35 , T. 33 N., R. 9 W. It forms a hill about $100 \mathrm{ft}(30 \mathrm{~m})$ high above 7,400 ft (2,255 m) on the rolling upland surface of Mesa Mountains. It is horizontally bedded near its base and is as thick as $16 \mathrm{ft}(4.8 \mathrm{~m})$. The gravel is composed of cobbles of quartzite and syenite porphyry and some gneiss and scarce granite. The composition is similar to that of gravel of the Animas River after softer sandstone clasts were removed by abrasion owing to river transport. A strong soil is developed in surficial clayey material.

Clues to its origin are horizontal bedding, its composition of the most resistant rock types in the Animas River drainage basin, its altitude high on the isolated Mesa Mountains in the San Juan Basin, and the presence of lag gravel scattered widely on the rolling upland surface. It appears to be a remnant terrace deposit of the Animas River about 1,480 ft $(451 \mathrm{~m})$ above the present river. An extensive fluvial gravel deposit probably formerly capped and protected the Mesa Mountains in Pliocene time.

\section{Landslide Deposit}

Landslide deposits of many ages, types, and sizes were studied. Most are slumped bedrock, but commonly the deposits also include some surficial deposits. Landslides commonly were caused by oversteepening of slopes in the Mancos or Lewis Shales or other clayey Upper Cretaceous rocks. Many deposits are more than $1 \mathrm{mi}^{2}\left(1.6 \mathrm{~km}^{2}\right)$ in area. One of these is partly buried by pre-Bull Lake till and outwash gravel (Moore and Gillam, 1984, p. 201). The slide deposits, which are apparently older than the glacial till, slid into an ancestral valley of the Animas River when the river flowed through the area now occupied by Fort Lewis College. On the scarp now facing westward toward Durango, the deposit is about $15-50 \mathrm{ft}$ (4-15 m) thick. It is composed chiefly of fragments of Point Lookout Sandstone and older, shaly Mesozoic rocks, but it also contains rounded clasts of granite. Some of the angular boulders are larger than $6 \mathrm{ft}(2 \mathrm{~m})$ in diameter. The slide deposits apparently originated on a hill to the west that was removed by erosion.

\section{Early Pleistocene (Blancan?) Outwash or Alluvium}

The second oldest alluvium in the study area is best preserved as a main stream deposit in center sec. 7 and NE $1 / 4$ sec. 18, T. 32 N., R. 9 W., La Plata County, Colorado, on the east side of the Animas River between the Florida River and New Mexico where it overlies the San Jose Formation. The deposit is coarse gravel containing well-rounded clasts of quartzite from the Uncompahgre Formation, hornblende gneiss, porphyritic dike rocks and volcanic rocks, granitic rocks, quartz, chert, siliceous rocks from Paleozoic limestone beds, and sandstone from the San Jose Formation. A strongly developed calcic layer with laminar structure, several inches thick, overlies the gravel. The gravel is on an erosion surface about $840 \mathrm{ft}(256 \mathrm{~m})$ above the Animas River. A cluster of potentially correlative (or possibly slightly older) deposits is on the west side of the Animas River about 900-1,000 ft (275-305 m) above the river in secs. 9, 16, and 24, T. 32 N., R. 10 W. Deposits were not found, and apparently are not preserved, along the other streams in the area. An inferred early Pleistocene (Blancan?) age is based solely on the position of 
the gravel in the geomorphic landform sequence. The gravel probably correlates with the Rocky Flats Alluvium in eastern Colorado, and possibly with the upper part of the Blanco Formation of Texas.

\section{Florida Gravel}

The Florida Gravel at its type locality caps Florida Mesa between the Animas River and the Florida River. Only the highest part of the mesa surface is capped by the type Florida Gravel as designated by Atwood and Mather (1932, plate 1 ); the lowest part of the mesa surface is capped by younger gravel that Richmond referred to as Sacagawea Ridge outwash. The highest gravel is 600-620 ft (183-190 m) above the Animas River, and it generally is about $500 \mathrm{ft}(153 \mathrm{~m})$ above other streams. The higher deposit (type Florida Gravel) is coarse gravel containing well-rounded clasts, including boulders larger than $3 \mathrm{ft}(0.9 \mathrm{~m})$ in diameter. The clasts along the Animas River, in order of decreasing abundance (in percentage of 100 samples), are porphyry (23), hornblende gneiss (20), quartzite (19), sandstone (17), aplite (5), siltstone (5), granite (3), granite gneiss (2), chert (2), limestone (2), vein or pegmatite quartz (1), and pegmatite (1). Clasts along the La Plata River are about 90 percent siliceous to intermediate volcanic and dike rocks; the rest are quartzite, banded purplish-gray or green argillite, and sandstone. More than 50 percent of the clasts are intensely weathered.

Florida Gravel equivalents crop out along the Animas, Florida, La Plata, Los Pinos, and San Juan Rivers and extend southwest as remnants along the San Juan River at least as far as Kirtland, New Mexico. The composition of the clasts varies depending on which stream deposited the gravel, but commonly quartzite and silicic volcanic rocks are best preserved. The gravel generally is $10-30 \mathrm{ft}(3-9 \mathrm{~m})$ thick, but locally it is thicker. The Florida Gravel was deposited as pediment covers and as fills along the main streams. Sorting and rounding are good in the terraced fill deposits. The gravel commonly is covered by reddish-brown or yellowish-brown loess.

\section{Lava Creek B Ash}

At several places the gravel is overlain by water-lain silt and volcanic ash. One sample of the ash was identified as Lava Creek B (G.A. Izett and R.E. Wilcox, 1982), which was erupted from a caldera at Yellowstone National Park approximately 639,000 years ago. A 2-ft-thick $(0.6 \mathrm{~m})$ bed of white to very pale brown ash was found above the gravel on a pediment west of Long Hollow in the $\mathrm{SW}^{1 / 4} \mathrm{SE}^{1 / 4} \mathrm{SW}^{1} / 4 \mathrm{sec}$. 11U, T. 34 N., R. 11 W., La Plata County. The ash also was found in several nearly contiguous places along the edges of the high remnants of Florida Gravel north and south of U.S. Highway 64, southeast of Durango. These outcrops, in E1/2 sec. 3, NW1/4 sec. 11, and NW1/4 NE1/4 sec. 12, T. 34 N., R. 9 W., La Plata County, are interpreted to be remnants of a formerly widespread sheet of ash in this local area. Here also, the ash is about $2 \mathrm{ft}(0.6 \mathrm{~m})$ thick, although not preserved continuously, and it overlies the Florida Gravel, well-sorted, 21-ft-thick (6.4 m), main-stem gravel, apparently outwash of early middle Pleistocene age. Locally, the ash is overlain by about $30 \mathrm{ft}$ $(9 \mathrm{~m})$ of poorly sorted pediment or fan gravel that includes pebbly, cobbly sand in the upper part. This gravel also is younger than the Florida Gravel and possibly is interglacial in age. In 1906, Woolsey (see also Larsen and Cross, 1956, p. 209-210; and Vanderwilt, 1947, p. 254) described volcanic ash that was being extracted from a pit in this same area-possibly from a pit near the center of the $\mathrm{NE}^{1 / 4} \mathrm{sec}$. 3, T. $34 \mathrm{~N}$., R. $9 \mathrm{~W}$.

Woolsey (1906) found ash at another site on a ridge about $420 \mathrm{ft}$ (128 m) above Junction Creek northwest of Durango. There the ash is about $10 \mathrm{ft}(3 \mathrm{~m})$ thick. Woolsey mentioned another ash bed "at the east end of the dry valley north of Animas City Mountain, on the shoulder of the southwardfacing spur." We were unable to find this ash bed. Three miles $(5 \mathrm{~km})$ north of Ignacio, Moore found a 3-ft-thick $(1 \mathrm{~m})$ ash bed near the crest of a gravel-capped hill on the west side of Los Pinos River, NE1/4 NW11/4 SE1/4 sec. 29, T. 34 N., R. 7 W., Durango 1:250,000 quadrangle.

A strongly developed Brown soil was examined at several places in the upper part of the Florida Gravel. The dark-reddish-brown B horizon is 1.5-3 ft (0.45-0.9 m) thick, is very clayey, and has a strong medium columnar structure and a hard, dry consistence. The $\mathrm{K}$ horizon is 3 to more than $4 \mathrm{ft}$ (0.9-1.2 m) thick and it consists of yellowish-gray, stony, clayey sand to gravel having laminar calcium carbonate (stage 4 of Gile, 1966) and rinds of calcium carbonate 0.5 inch $(1.2 \mathrm{~cm})$ thick on the bottoms of stones. A podzolic soil about $2 \mathrm{mi}(3.2 \mathrm{~km})$ south of Hesperus in NW1/4 SW1/4 sec. 25, T. 35 N., R. 11 W., La Plata County, Colorado, contains the following horizons: A1, 6 inch $(15 \mathrm{~cm})$; A2, 8 inch $(20 \mathrm{~cm})$; B1, 14 inch $(36 \mathrm{~cm})$; B2, 20 inch $(51 \mathrm{~cm})$; and weathered C (parent material-early middle Pleistocene outwash).

The age of the Florida Gravel, based on the age of the overlying Lava Creek B ash, is early middle Pleistocene. It was interpreted by Richmond (1965, p. C139) to have been deposited during his Sacagawea Ridge glaciation.

\section{Pediment Alluvium of Middle Middle Pleistocene Age}

Overlying the Florida Gravel and the Lava Creek ash locally is approximately $30 \mathrm{ft}(9 \mathrm{~m})$ of yellowish-gray to purplish-gray, poorly sorted, crudely stratified, pebbly, cobbly gravel and sand that contains boulders as large as $2 \mathrm{ft}(0.6 \mathrm{~m})$ in diameter. Most of the clasts are sedimentary rock types that are exposed nearby. The purplish-gray color is derived from the McDermott Member of the Animas Formation. Locally, the sand is well cemented. This deposit is well preserved on a southward-facing valley wall in the $\mathrm{SE}^{1 / 4}$ sec. 3 , T. 34 N., R. 9 W., La Plata County, Colorado (Loma Linda 71/2-minute 
quadrangle). The gravel is correlated with the Verdos Alluvium in the Denver, Colorado, area.

Atwood and Mather (1932) believed that a "Canyon cycle of erosion" ended the "Florida cycle of erosion." Actually, the depth of erosion following deposition of the Florida Gravel was only about $140 \mathrm{ft}$ (42 m), which is not even as much as the interval between some of the other alluvial units. Therefore, we do not believe that this erosional interval should be distinguished by a separate name. Erosion of canyons in the area apparently began at a time we estimated as the end of the Miocene.

\section{Durango Till}

At the north end of the unnamed high mesa that is the home of Fort Lewis College are deposits of till that possibly represent two intervals of late middle Pleistocene Durango glaciation. At least one of the moraines, probably the youngest, is composed of the type Durango Till of Atwood and Mather (1932). The till was attributed to the Sacagawea Ridge glaciation by Richmond (1965). The oldest of the presumed two moraines trends northeastward and is just west and southwest of the City Reservoir No. 1. This moraine is inferred to be either an earlier moraine of Durango Till or the moraine of an earlier temporary stillstand of the glacier that deposited the younger moraine of Durango Till. A good exposure of the till in the older moraine was not found, but a shallow trench exposed a soil that is equally as well developed-if not more strongly developed-than the soil on the younger moraine. This older till is compact, bouldery, and nonsorted. The composition is similar to that of the younger till; however, most of the clasts are completely weathered. Clasts of dike rocks, siltstone, sandstone, quartzite, and some plutonic rocks are relatively unweathered.

The youngest of the presumed two tills forms a northeast-trending ridge just north of City Reservoir No. 1 on the Durango East $71 / 2$-minute quadrangle. The ridge is rather smooth and has gentle slopes. Boulders project above its surface, perhaps one-fourth to one-third of their diameters. The till is reddish brown or mottled, compact, bouldery, sandy, and nonsorted. Clasts are hornblende gneiss, quartzite, granite, quartz monzonite, granodiorite (some gneissoid), a few volcanic or dike rocks, limestone (especially siliceous [chert?] fragments), sandstone, and shale. Many clasts are intensely weathered. The upper part of the till contains a well-developed soil having a B horizon as thick as 54 inches $(137 \mathrm{~cm})$. The horizon is reddish brown, clayey, blocky, and very plastic. A Cca horizon thicker than 36 inches $(91 \mathrm{~cm})$ underlies the $\mathrm{B}$ horizon and contains white calcium carbonate that is very firmly cemented. The calcium carbonate forms rinds as thick as 0.25 inch $(6 \mathrm{~mm})$ on the undersides of clasts. The till is at least $25 \mathrm{ft}(7.6 \mathrm{~m})$ and possibly as much as $160 \mathrm{ft}(49 \mathrm{~m})$ thick.

\section{Late Middle Pleistocene Outwash(?)}

Two terrace surfaces along the Animas River are $500 \mathrm{ft}$ (152 $\mathrm{m})$ and 420-440 ft (128-134 $\mathrm{m})$ above the river. The lithology of these deposits is almost identical with that of the Durango outwash. Soils are more strongly developed than those on the Wisconsinan-age deposits.

\section{Lower Durango Outwash and Alluvium}

Remnants of an outwash plain of a late middle Pleistocene Durango glaciation underlie a terrace $310-400 \mathrm{ft}$ (95-122 m) above the Animas River south of Durango. This terrace was mapped as Durango outwash by Atwood and Mather (1932). Southward into New Mexico, the terrace surface is $300-360 \mathrm{ft}(92-110 \mathrm{~m})$ above the Animas and San Juan Rivers.

Gravel beneath the terrace ranges in thickness from 12 to $28 \mathrm{ft}(3.6-8.5 \mathrm{~m})$. Boulders are as large as $8 \mathrm{ft}(2.4 \mathrm{~m})$ in diameter near the terminal moraine east of Durango but decrease in size downstream so that near Farmington, New Mexico, few are larger than $1 \mathrm{ft}(0.3 \mathrm{~m})$. The clasts are chiefly quartzite from the Uncompahgre Formation, porphyritic volcanic and dike rocks, granite, quartz monzonite, granodiorite, quartz diorite, sandstone, hornblende gneiss, quartzite, quartz, conglomerate, siliceous fossiliferous fine-grained Paleozoic rocks, and local limestone and dolomite, some of which contain chert nodules. Sedimentary clasts decrease in relative abundance downstream. Just south of Durango, the upper $10 \mathrm{ft}$ (3 m) of the gravel contains boulders $6-8 \mathrm{ft}(1.8-2.4 \mathrm{~m})$ in maximum dimension, whereas the average size is only a foot or so. We suggest that the large boulders were deposited during a catastrophic glacial meltwater flood.

A soil in the upper part of the outwash contains a moderate-reddish-brown B horizon $3.5 \mathrm{ft}(1.1 \mathrm{~m})$ thick that has a strong, medium blocky structure and is sticky and plastic when wet and hard consistence when dry. The sandy, platy Cca (or $\mathrm{K})$ horizon contains pebbles having calcium carbonate rinds about 1 inch $(2.5 \mathrm{~cm})$ thick.

\section{Upper Durango Outwash}

Remnants of an outwash plain of a late Durango glaciation were traced southward from Durango as terrace remnants 230-340 ft (70-104 m) above the Animas River. The outwash consists of bouldery, cobbly, stratified, fairly well sorted alluvium. The outwash is more than $10 \mathrm{ft}(3 \mathrm{~m})$ thick, and it commonly is overlain by more than $10 \mathrm{ft}(3 \mathrm{~m})$ of sandy fan alluvium, especially along the south side of the Animas River northeast of Farmington, N. Mex. The lithology of the outwash is similar to that of the lower Durango outwash. The soil also is similar, but it is not as strongly developed. 


\section{Lower Spring Creek Till}

Till, apparently of an early Spring Creek glaciation (early Bull Lake stade of Richmond, 1965), is present in three small, gently rounded remnants of a terminal moraine $2-3$ miles (3-5 km) east of Durango along the Florida road. The till is greatly dissected and thinner than usual (less than $25 \mathrm{ft}$ ). The deposits are bouldery, sandy, nonsorted, and nonstratified. A strongly developed soil in the upper part contains a B horizon 20 inches $(51 \mathrm{~cm})$ thick that is moderate reddish brown, very clayey, and blocky. An underlying Cca horizon is $2 \mathrm{ft}(0.6 \mathrm{~m})$ thick.

\section{Lower Spring Creek Outwash}

A discontinuous terrace underlain by lower Spring Creek outwash is present along the Animas and other rivers in the study area. The terrace surface ranges from 130 to $170 \mathrm{ft}$ (43-52 m) above the rivers. The outwash, which is $20-30 \mathrm{ft}$ $(6-9 \mathrm{~m})$ thick, is poorly sorted and is composed of boulders as large as $12.5 \mathrm{ft}(3.8 \mathrm{~m})$, cobbles, pebbles, and a sand matrix; it is fairly well washed and contains little silt or clay. The large clasts, chiefly locally derived sedimentary rocks, suggest that the upper part of the outwash was deposited by a catastrophic meltwater flood. A soil in the upper part contains an A horizon about 12 inches $(30 \mathrm{~cm})$ thick, and a light-brown to reddishbrown B horizon 20-30 inches $(51-76 \mathrm{~cm})$ thick that has a fine, strong, blocky structure and a sticky, plastic, hard consistence. In the underlying Cca horizon about 3 to 4.5 -ft- ( 0.9 to $1.4 \mathrm{~m})$ thick rinds of calcium carbonate 0.5 inch $(1.3 \mathrm{~cm})$ thick coat the undersides of cobbles. Along the Animas River the outwash is composed of quartzite, hornblende gneiss, granitic rocks, gabbroic rocks, porphyry, and resistant sedimentary rocks.

\section{Upper Spring Creek Till}

Till, apparently deposited by a late Spring Creek glacier (late Bull Lake stade of Richmond, 1965), forms a terminal moraine in the northern part of Durango. The moraine is preserved as five remnants of a former looplike moraine with as much as $150 \mathrm{ft}(45 \mathrm{~m})$ of relief. The remnants are gently rounded, and few boulders project more than one-third of their diameters above the surface of the moraine. The till is bouldery, clayey, nonsorted, and nonstratified. A soil in the upper part contains a brownish-gray, silty, humus-rich A horizon $10-12$ inches $(25-30 \mathrm{~cm})$ thick that has a weak platy structure. The underlying B horizon is $20-24$ inches $(50-60 \mathrm{~cm})$ thick, is moderate reddish brown, clayey, and very plastic when moist and hard when dry. An underlying Cca horizon is concentrated through about $4 \mathrm{ft}(1.2 \mathrm{~m})$ of the parent till; it contains rinds of calcium carbonate $1 / 3$ to $3 / 16$ inch $(8-10 \mathrm{~cm})$ thick on the undersides of cobbles. The till is composed of hornblende gneiss, quartzite, granite, quartz monzonite, granodiorite (some foliated), a few volcanic or dike rocks, limestone, ironstone, sandstone, and shale.

\section{Upper Spring Creek Outwash}

A fairly continuous terrace underlain by upper Spring Creek outwash is present along the Animas and other rivers. The terrace surface is $90-120 \mathrm{ft}(27-36 \mathrm{~m})$ above the streams, and the gravel is $20-30 \mathrm{ft}(6-9 \mathrm{~m})$ thick. The outwash is moderate reddish brown and is fairly well sorted in the lower part where it contains boulders as large as 24 inches $(61 \mathrm{~cm})$ in diameter. The lower $15 \mathrm{ft}$ of the deposit, $2 \mathrm{mi}(3.2 \mathrm{~km})$ downstream from the moraine and on the west side of the Animas River just downstream from the mouth of Junction Creek, is composed chiefly of porphyry, sandstone, and siltstone clasts. The porphyry was transported by Junction Creek from the La Plata volcanic center. The upper $15 \mathrm{ft}(4.5 \mathrm{~m})$ of the deposit at the same place is poorly sorted; it contains many boulders 6-12 ft (1.8-2.4 m) in diameter, indicating that it may have been deposited by a catastrophic flood. Well-rounded clasts in the upper part are chiefly sedimentary and igneous rocks transported by the Animas River. They are composed of granite, quartz diorite, granodiorite, quartz monzonite, hornblende gneiss, quartzite, sandstone, and dolomite. A soil in the upper part contains a reddish-brown A horizon 6 inches $(15 \mathrm{~cm})$ thick, a reddish-brown, very clayey B horizon $2-4 \mathrm{ft}$ (0.6-1.2 m) thick, and a 3.5-ft-thick Cca horizon. Calcium carbonate forms crusts $1 \mathrm{~mm}$ thick on the undersides of clasts. Locally, as in the SE $1 / 4$ sec. 24 , T. 34 N., R. 10 W., the soil is a podzolic soil and it contains no Cca horizon; there, the $\mathrm{B}$ horizon is $4 \mathrm{ft}(1.2 \mathrm{~m})$ thick, is grayish red, and extremely clayey. At a gravel pit in the Aztec quadrangle a conglomerate bed $4 \mathrm{ft}$ $(1.2 \mathrm{~m})$ thick, cemented by calcium carbonate, was exposed about $4.6 \mathrm{ft}(1.2-1.8 \mathrm{~m})$ above the base of the gravel.

\section{Loess}

Loess of at least two ages was observed. The older loess is interpreted to be early or late middle Pleistocene in age; the younger loess probably is late Pleistocene in age.

The older loess is generally silty clay that is strongly oxidized to a moderate reddish-brown color. An A horizon has a strong prismatic structure and is 18 inches $(45 \mathrm{~cm})$ thick. A $\mathrm{B}$ horizon also has a strong prismatic structure, very clayey consistence, and is about 40 inches $(100 \mathrm{~cm})$ thick. A Cca horizon contains calcium carbonate coatings, veinlets, and hard nodules and locally is about $5 \mathrm{ft}(1.5 \mathrm{~m})$ thick.

The younger loess is yellowish-brown or grayish-orange, clayey silt that locally is more than $20 \mathrm{ft}(6 \mathrm{~cm})$ thick.

\section{Lower Animas City Till}

A terminal moraine formed by an early Pinedale glacier (early stade of Richmond, 1965) is a nearly continuous loop 
across the Animas River at the north end of Durango. The moraine is fairly sharp crested and steep sided. Most of the surface boulders project about one-half of their diameters above the till surface. The till is brown, bouldery, sandy, nonsorted, and nonstratified. It contains boulders larger than $8 \mathrm{ft}(2.4 \mathrm{~m})$ in diameter. A soil in the upper part contains a brownish-gray, sandy, clayey, hard, blocky A horizon 1-8 inches $(2.5-20 \mathrm{~cm})$ thick, underlain by a moderate-reddish-brown, pebbly, cobbly B horizon. The B horizon is $14-24$ inches $(35-60 \mathrm{~cm})$ thick, is very clayey, has strong, medium columnar structure, and is sticky and plastic when moist and hard when dry. An underlying light-brown, sandy, stony Cca horizon is 30-36 inches $(75-90 \mathrm{~cm})$ thick.

\section{Middle Animas City Till}

A terminal moraine deposited by a middle Pinedale glacier is just north of the moraine of the early Pinedale glacier. The term middle (middle stade of Richmond, 1965) is based on an assumption that a still younger Pinedale moraine is present farther up the valley of the Animas River. Richmond (1965) mentioned seeing a terminal moraine of a late Pinedale glacier, but we did not search for a moraine. Johnson (1990) recognized an end moraine segment near Baker's Bridge, $12 \mathrm{mi}(20 \mathrm{~km})$ north of Durango. Whether this is a terminal moraine or a recessional moraine is not clear.

The middle Animas City moraine is sharp crested, steep sided, and somewhat hummocky in spite of its narrowness. Most of the surface boulders project one-half to two-thirds of their diameters above the surface of the moraine. The till is light brown, compact, sandy, bouldery, nonsorted, and nonstratified. A soil in the upper part contains a brownish-gray, sandy, clayey, blocky, hard A horizon 8-12 inches $(20-10 \mathrm{~cm})$ thick, underlain by a moderate-reddish-brown, clayey B horizon. The B horizon is $12-18$ inches $(30-45 \mathrm{~cm})$ thick, and it has a moderately strong, medium columnar structure. It has a sticky plastic consistence when moist and it is very hard when dry. An underlying light-brown Cca horizon, 22-30 inches $(55-75 \mathrm{~cm})$ thick, is sandy. Clasts have rinds of calcium carbonate one-eighth to one-fourth inch $(3-6 \mathrm{~cm})$ thick on their undersides.

\section{Upper Animas City Outwash}

A terrace composed of upper Animas City outwash is nearly continuous along the Animas River south of the terminal moraines. The outwash is bouldery, cobbly alluvium containing a loose, sandy matrix. Only one terrace, about $50 \mathrm{ft}$ (15 m) above the river, is present immediately south of the two moraines. At several places in the Loma Linda quadrangle, however, are two terraces, $40 \mathrm{ft}$ and $60 \mathrm{ft}$ (12 and $18 \mathrm{~m})$ above the river. Probably each glacier produced an outwash plain, but meltwater from the middle Pinedale glacier removed most of the outwash of the early Pinedale glacier. Partial erosion of the $60-\mathrm{ft}(18-\mathrm{m})$ terrace is well illustrated in the center of sec. $8 \mathrm{U}$, southern T. 34 N., R. 9 W., in the Loma Linda quadrangle.

A soil in the upper part of the outwash contains a moderate-brown, sandy, humus-rich, silty A horizon about 3 inches $(7 \mathrm{~cm})$ thick. An underlying, moderate brown or grayish-red, clayey B horizon 8-20 inches $(20-50 \mathrm{~cm})$ thick generally has a fine moderate prismatic or a medium strong blocky structure. It is sticky and has a plastic consistence when moist and is hard when dry. Locally, the B horizon is sandy, platy, and only slightly hard. An underlying grayish-red Cca horizon is about 14 inches $(35 \mathrm{~cm})$ to more than $5.5 \mathrm{ft}(1.7 \mathrm{~m})$ thick and is very weak (probably stage 1 or 2 of Gile, 1966). The rind of calcium carbonate on the bottoms of clasts is only 0.4-0.7 inch (1-2 mm) thick.

The outwash along the Animas River is composed of porphyry, granitoid rocks, hornblende gneiss, and fragments of quartzite from the Uncompahgre Formation, sandstone, and limestone. Some boulders are as large as $5 \mathrm{ft}(1.5 \mathrm{~m})$ in diameter.

\section{Fan Alluvium}

Alluvium in fans was observed at many places, but the thickest accumulation is along the southeast side of the Animas River in the Aztec quadrangle, New Mexico. Most of the fan alluvium ranges in age from Bull Lake to Holocene. Generally, it is granular or pebbly sand but locally is gravel. The thickness of the fan deposits probably averages about $15 \mathrm{ft}$ $(5 \mathrm{~m})$ but locally is much more. Evidence that there are several ages of fans is provided by the soils. The fan overlying the terrace of early Bull Lake age has a B horizon 10-12 inches $(25-30 \mathrm{~cm})$ thick and a Cca horizon 3-6 ft $(1.9-1.8 \mathrm{~m})$ thick; the fan overlying the terrace of late Bull Lake age has a B horizon $0.4-0.8 \mathrm{ft}(12-24 \mathrm{~cm})$ thick and a Cca horizon $0.9 \mathrm{ft}$ $(27 \mathrm{~cm})$ thick; the fan overlying the Pinedale terrace has a B horizon 0.8-1.0 ft (24-30 cm) thick and a Cca horizon $1.5-1.9 \mathrm{ft}(45-57 \mathrm{~cm})$ thick. Although thicker, it has weaker development than the Cca horizons on the other fan deposits.

\section{Tsegi Alluvium}

A deposit of alluvium in most of the valleys is correlated with the Tsegi Alluvium of Hack (1941). The alluvium generally underlies a terrace about 10-20 ft (3-6 m) above stream level or arroyo bottom. The Tsegi is brownish-gray sand and silt layers that commonly are $1 / 4$ inch to $2 \mathrm{ft}(0.6-0.6 \mathrm{~m})$ thick. Gravel layers a few inches thick generally are present in the lower part. The deposit is rich in humus. A soil in the upper part is weakly developed. It has only a slight color or clay increase in the B horizon and rarely has a Cca horizon containing spots of calcium carbonate $1 / 8$ inch $(0.3 \mathrm{~cm})$ in diameter. The thickness is as much as $20 \mathrm{ft}(6 \mathrm{~m})$. 


\section{Pliocene and Quaternary Deposits in the Northern Part of the San Juan Basin in Southwestern Colorado and Northwestern New Mexico}

\section{Naha Alluvium}

The youngest alluvium that forms a terrace is correlated with the Naha Alluvium of Hack (1941). The terrace surface generally is less than $10 \mathrm{ft}(3 \mathrm{~m})$ above arroyo floors. The Naha is grayish-brown, well-bedded to cross-stratified, friable to slightly compact sand. It contains no zonal soil, but the upper few inches is humic-rich. The thickness generally is less than $10 \mathrm{ft}(3 \mathrm{~m})$.

\section{Validity of the Deposits}

When we started this geologic investigation we had concerns regarding the validity of stratigraphic names, the locations of certain named deposits, the accuracy of the mapped contacts of all units, and the ages of many.

The Bayfield Gravel was named by Atwood and Mather (1932) who stated, "Pebbles and cobblestones of bluish quartzite and milky-white quartz, as much as 6 inches in diameter, rest on the highest part of Animas City Mountain, $3 \frac{1}{2} \mathrm{mi}$ north of Durango, at altitudes up to $8,170 \mathrm{ft}$. This is the type locality for the formation." However, they named the formation for the town of Bayfield, about 14 mi east of Durango, where they found "scattered pebbles, cobblestones and boulders" on several flat-topped hills, rather than for Animas City Mountain, the type locality. They correlated deposits at other sites with their Bayfield Gravel. Richmond (1965) mapped "Bayfield gravel" on the summits of Rules Hill and nearby hills $6 \mathrm{mi}(10 \mathrm{~km})$ northwest of Bayfield.

Glenn R. Scott and John D. Strobell examined the surface of both Animas City Mountain and the hills northeast of Bayfield and found only sparse, scattered, rounded clasts in both places. D.W. Moore and Jay Stravers later examined Rules Hill and nearby hill summits northwest of Bayfield. There is no gravel on Rules Hill. On a hill many yards $(0.5 \mathrm{~km})$ southeast of Rules Hill are scattered a few hundred pebbles of volcanic rhyolite porphyry. They are presently weathering out of the underlying bedrock, an arkosic conglomeratic sandstone, part of the Upper Cretaceous and Paleocene Animas Formation. The beds strike N. $70^{\circ} \mathrm{E}$. and dip $40^{\circ} \mathrm{S}$., conformable with Upper Cretaceous beds that form the bedrock hogback there. The scattered pebbles on the hill are residual and modern. They have not been transported by a river in Quaternary time, as required if they are correlated with the Bayfield Gravel. They form no significant deposit of alluvium; therefore, we believe that the term Bayfield Gravel is completely unnecessary.

Richmond (1965, p. C142) reexamined the Oxford Gravel of Atwood and Mather (1932) and found it to be colluvium. Richmond stated, "As such it is not stratigraphically significant to subdivision of the Quaternary of the area." We too studied the Oxford and found in some places it is lag gravel that originated from older, topographically higher gravel deposits. We agree with Richmond that the deposit lacks geomorphic significance; therefore, we believe that the name Oxford Gravel is completely unnecessary.

Dickinson (1965) examined the Cerro Till of Atwood (1916) at its type locality on Cerro Summit in Colorado. Because there was no till, but only mass-wasting debris at the type locality, Dickinson abandoned the name Cerro Till. Some workers (for instance Richmond [1986]) suggested that some deposits elsewhere that were formerly mapped as Cerro Till may actually be till; if so, for those deposits a new name should be applied and their lithology, geomorphic position, age, and all other required information for a newly named deposit should be published.

Concerning the Bridgetimber Gravel, Richmond (1965, p. C141) stated, "The gravel on the lower [southern] surface of Bridge Timber Mountain is 20-40 ft thick." We found only lag gravel on the lower and southern part of Bridge Timber Mountain. Only the Bridgetimber Gravel that caps the upper and northern part of the mountain has geomorphic significance.

The Los Pinos Formation (Atwood and Mather, 1932) apparently was named by E.S. Larsen for exposures in the canyon of Los Pinos Creek, near the town of San Miguel in the extreme northern part of New Mexico about 10-12 mi (16$18 \mathrm{~km}$ ) southwest of Antonito, Colorado. Atwood and Mather assigned a Pliocene(?) age to the Los Pinos and equated it with the Bayfield and Bridgetimber Gravels. Lipman (1975) assigned an age of Pliocene to Oligocene to the Los Pinos and stated that it underlies and interfingers with basalt flows of the Hinsdale Formation that vary in age from about 5 to 23 m.y. (Miocene and Pliocene). If the Los Pinos is indeed of that age, it would now be considered early Miocene.

\section{Geomorphology}

The most comprehensive discussion of the geomorphology of the San Juan Mountains and surrounding region is that of Atwood and Mather (1932). Unfortunately, many if not most of their conclusions about glaciation, peneplanation, canyon cutting, and even deposition are invalid, largely because of the invalidity of many of the deposits upon which the postulated events were based, as we have stated earlier in this report. In addition, several important events were omitted from Atwood and Mather's geomorphic history. Omissions include erosion of the late Eocene surface and several stages of canyon cutting and fluvial deposition.

The earliest event that exerted a major influence on the physiography of the area was the cutting of a late Eocene erosion surface. This extensive surface developed on Precambrian rocks was widespread. The surface was later covered by alluvial gravel called by several names at different places: Telluride Conglomerate, Blanco Basin Formation, El Rito Formation, San Jose Formation, and Ritito Formation. These probable Eocene and younger deposits were then covered by volcanic or volcaniclastic deposits that generally were of local derivation and of Oligocene and Miocene age. They include 
from oldest to youngest, among other deposits, the Conejos Formation, then a series of ash-flow tuffs, then the Los Pinos Formation, and finally the Hinsdale Formation. Atwood and Mather (1932) also inferred the development of a widespread, so-called San Juan peneplain that supposedly formed during the transition between the Pliocene and Pleistocene. Steven (1968) reviewed the evidence concerning the concept of a San Juan peneplain and decided that such a surface never existed. He concluded that, "The detailed volcanic and geomorphic history of the central San Juan Mountains indicates no peneplain cycle of erosion between the end of major volcanism and the present time."

We find that the large-scale eruptive and aggradational event that resulted in the deposition of volcanic and volcaniclastic rocks had ceased by the end of Miocene time. Canyon cutting began in the Pliocene and still continues. The first fluvial material deposited then was the Bridgetimber Gravel. It probably was deposited 2.5-3.0 m.y. ago and is about $1,150 \mathrm{ft}$ to $2,000 \mathrm{ft}$ ( 350 to $640 \mathrm{~m}$ ) above the modern rivers. At about the same time or earlier, gravel on Mesa Mountains may have been deposited by the Animas River. The next younger alluvial deposit is yet unnamed; it is $845-900 \mathrm{ft}(258-274 \mathrm{~m})$ or $1,000 \mathrm{ft}(300 \mathrm{~m})$ above the Animas River. It probably is early Pleistocene (Blancan?) in age. No evidence was found to relate these last deposits to glaciation. The next younger alluvial deposit is the Florida Gravel, which is interpreted to be glacial outwash in spite of a lack of direct evidence to confirm a glacial association. The Florida Gravel is about 500-640 ft (152-195) above the Animas River; it is early middle Pleistocene in age and slightly older than 639,000 years. Very soon after deposition of the Florida Gravel, an airfall volcanic ash (the Lava Creek B ash from Yellowstone National Park) was deposited across this area and much of the Great Plains. It was concentrated by water in locally thick deposits. Local nonglacial alluvium was almost immediately deposited on the ash.

Two late middle Pleistocene terraces are at $500 \mathrm{ft}(152 \mathrm{~m})$ and $400 \mathrm{ft}(122 \mathrm{~m})$ above the Animas River. They possibly represent one or two glaciations between the Florida and Durango events. The next younger episode of alluviation is probably also of late middle Pleistocene age. It is correlated with the Durango Till, which is on the high surface occupied by Fort Lewis College east of Durango. Two stages of glaciation are inferred to have occurred in Durango Till time. The corresponding outwash surfaces are about $360 \mathrm{ft}(110 \mathrm{~m})$ and $340 \mathrm{ft}(104 \mathrm{~m})$ above the Animas River. The gradual and stepped decrease in altitude of the alluvial deposits above a given reach of the river through time indicates that canyons were cut progressively deeper throughout Pliocene and Quaternary time.

In late middle Pleistocene (Spring Creek or Bull Lake) time, glaciers advanced as far south as Durango twice and deposited outwash gravel on the valley floor. The gravel now underlies terraces 130-170 ft (40-52 m) and $120 \mathrm{ft}(30 \mathrm{~m})$ above modern streams. Similarly, in Pinedale time glaciers reached Durango twice and deposited outwash gravel that now underlies terraces $60 \mathrm{ft}(18 \mathrm{~m})$ and $40 \mathrm{ft}(12 \mathrm{~m})$ above streams.
Loess derived from fine-grained outwash was deposited on valley deposits in middle Pleistocene time and again in late Pleistocene time. Eolian sand was deposited from near the end of the Pleistocene until early Holocene time. Clayey fan alluvium, derived chiefly from Upper Cretaceous marine shale, was washed onto valley floors and terrace gravel throughout the Quaternary Period.

Icecap glaciation was inferred by Atwood and Mather (1932), by Richmond (1965), and by Leonard (1979). We follow an accepted definition of an icecap: "A dome-shaped or platelike cover of perennial ice and snow, covering the summit area of a mountain mass so that no peaks emerge through it" (Bates and Jackson, 1980, p. 307). We would not call the apparent glacial maximum in the San Juan Mountains an "icecap" because the highest glacial scouring is many tens or even a few hundred meters below most high peak summits. In other words, it was an ice field.

Apparently the chief reason that Atwood and Mather suggested that this was icecap glaciation was their belief in the glacial origin of the so-called Cerro Till; it is a widespread landslide deposit, not a till sheet. On a map showing the extent of glaciers, Atwood and Mather extended the margins of many glaciers beyond the confines of the valleys. We plotted the upper limits of many of the glaciers and found that in every area studied, the glacier boundaries were more restricted than shown by Atwood and Mather (1932).

An independent approach by Porter and others (1983) used paleoclimatic factors to model a late Wisconsinan ice field in the San Juan Mountains. Their ice field was about $1,000 \mathrm{~m}$ thick, $10-25 \mathrm{~km}$ south of the Animas River-Uncompahgre River divide. Ice flowed over many divides, but whether most high peaks were above the ice surface is a moot question. Our field examination suggests that the ice scoured some divides (for example Weminuche Pass) (lat $37^{\circ} 43^{\prime}$ N., long $107^{\circ} 43^{\prime}$ W.) between the Animas River and the headwaters of Lime Creek. Nevertheless, we do not see justification for use of the term icecap glaciation. Gillam and others (1984, p. 154) also questioned Atwood and Mather's concept of the so-called icecap, "Although they called this mass of ice an icecap, they recognized that the ice was mostly confined to valleys and rarely crossed drainage divides."

\section{References Cited}

Atwood, W.W., 1911, Physiographic studies in the San Juan district of Colorado: Journal of Geology, v. 19, p. 449-453.

Atwood, W.W., 1916, Eocene glacial deposits in southwestern Colorado: U.S. Geological Survey Professional Paper 95-B, p. 13-26.

Atwood, W.W., and Mather, K.F., 1912, The evidence of three distinct glacial epochs in the Pleistocene history of the San Juan Mountains, Colorado: Journal of Geology, v. 20, p. 385-409. 


\section{Northwestern New Mexico}

Atwood, W.W., and Mather, K.F., 1932, Physiography and Quaternary geology of the San Juan Mountains, Colorado: U.S. Geological Survey Professional Paper 166, 176 p.

Baltz, E.H., 1967, Stratigraphy and regional tectonic implications of part of Upper Cretaceous and Tertiary rocks, east-central San Juan Basin, New Mexico: U.S. Geological Survey Professional Paper 552, 101 p.

Bandoian, C.A., 1969, Geomorphology of the Animas River valley, San Juan County, New Mexico: Albuquerque, University of New Mexico, Master's thesis, 88 p.

Barnes, Harley, Baltz, E.H., and Hayes, P.T., 1954, Geology and fuel resources of the Red Mesa area, La Plata and Montezuma Counties, Colorado: U.S. Geological Survey Oil and Gas Investigations Map OM 149, scale 1:62,500.

Bates, R.L., and Jackson, J.A., 1980, Glossary of geology (2d ed.): Falls Church, Va., American Geological Institute, $751 \mathrm{p}$.

Dickinson, R.G., 1965, Landslide origin of the type Cerro Till, southwestern Colorado: U.S. Geological Survey Professional Paper 525-C, p. C147-151.

Gile, L.H., 1966, Cambic and certain noncambic horizons in desert soils of southern New Mexico: Soil Science Society of America Proceedings, v. 30, no. 6, p. 773-781.

Gillam, M.L., 1982, Quaternary alluvial deposits and soil formation, lower Animas River area, Colorado and New Mexico: Geological Society of America, Cordilleran Section, 78th annual meeting, abstracts with programs, p. 166.

Gillam, M.L., Moore, D.W., and Scott, G.R., 1984, Quaternary deposits and soils in the Durango area, southwestern Colorado, in Brew, D.C., ed., Rocky Mountain Section Field Trip Guidebook: Geological Society of America, Rocky Mountain Section Field Trip Guidebook 37th Annual Meeting; Durango, p. 149-182.

Hack, J.T., 1941, Dunes of the western Navajo country: Geographical Review, v. 31, no. 2, p. 240-263.

Haynes, D.D., Vogel, J.D., and Wyant, D.G., 1972, Geology, structure, and uranium deposits of the Cortez quadrangle, Colorado and Utah: Department of the Interior, U.S. Geological Survey, Miscellaneous Investigations Series, Map I-629, scale: 1:250,000
Izett, G.A., and Wilcox, R.E.,1982, Map showing localities and inferred distributions of the Huckleberry Ridge, Mesa Falls, and Lava Creek ash beds in the western United States and southern Canada: U.S. Geological Survey Miscellaneous Investigations Map I-1325, scale 1:4,000,000.

Johnson, M.D., 1990, Fabric and origin of diamictons in end moraines, Animas River Valley, Colorado, U.S.A.: Arctic and Alpine Research, v. 22, no. 1, p. 14-25.

Larsen, E.S., Jr., and Cross, Whitman, 1956, Geology and petrology of the San Juan region southwestern Colorado: U.S. Geological Survey Professional Paper 258, 303 p.

Leonard, E.M., 1979, Topography and glaciation in the San Juan Mountains and Front Range, Colorado: Geological Society of America abstracts with programs, v. 11, no. 6, p. 277.

Lipman, P.W., 1975, Evolution of the Platoro caldera complex and related volcanic rocks southeastern San Juan Mountains, Colorado: U.S. Geological Survey Professional Paper 852,128 p. (see p. 77 ).

Moore, D.W., and Gillam, M.L., 1984, Road log-Quaternary deposits and soils in the Durango area, southwestern Colorado, in Brew, D.C., ed., Rocky Mountain Section Field Trip Guidebook: Geological Society of America, 37th annual meeting, Durango, Colo., p. 183-209.

Pastuszak, R.A., 1968, Geomorphology of part of the La Plata and San Juan Rivers, San Juan County, New Mexico: Albuquerque, University of New Mexico, Master's thesis, $84 \mathrm{p}$.

Porter, S.C., Pierce, K.T., and Hamilton, T.D., 1983, Late Wisconsin mountain glaciation in the western United States, in Porter, S.C., ed., Late Quaternary environments of the United States, volume 1-The late Pleistocene: Minneapolis, University of Minnesota Press, p. 71-110

Richmond, G.M., 1965, Quaternary stratigraphy of the Durango area, San Juan Mountains, Colorado: U.S. Geological Survey Professional Paper 525C, p. C137-143. 
Richmond, G.M., 1986, Stratigraphy and correlation of glacial deposits of the Rocky Mountains, the Colorado Plateau, and the ranges of the Great Basin: p. 99-122, in Richmond, G.M., and Fullerton, D.S., Quaternary glaciation in the United States of America: Quaternary Science Reviews, v. 5.

Steven, T.A., 1968, Critical review of the San Juan peneplain, southwestern Colorado: U.S. Geological Survey Professional Paper 594-I, p. I1-I19.
Vanderwilt, J.W., 1947, Mineral resources of Colorado: State of Colorado Mineral Resources Board, 547 p.

Wanek, A.A., 1959, Geology and fuel resources of the Mesa Verde area, Montezuma and La Plata Counties, Colorado: U.S. Geological Survey Bulletin 1072 M, p. IV, 667-721.

Woolsey, L.H., 1906, Volcanic ash near Durango, Colorado: U.S. Geological Survey Bulletin 285, p. 476-479.

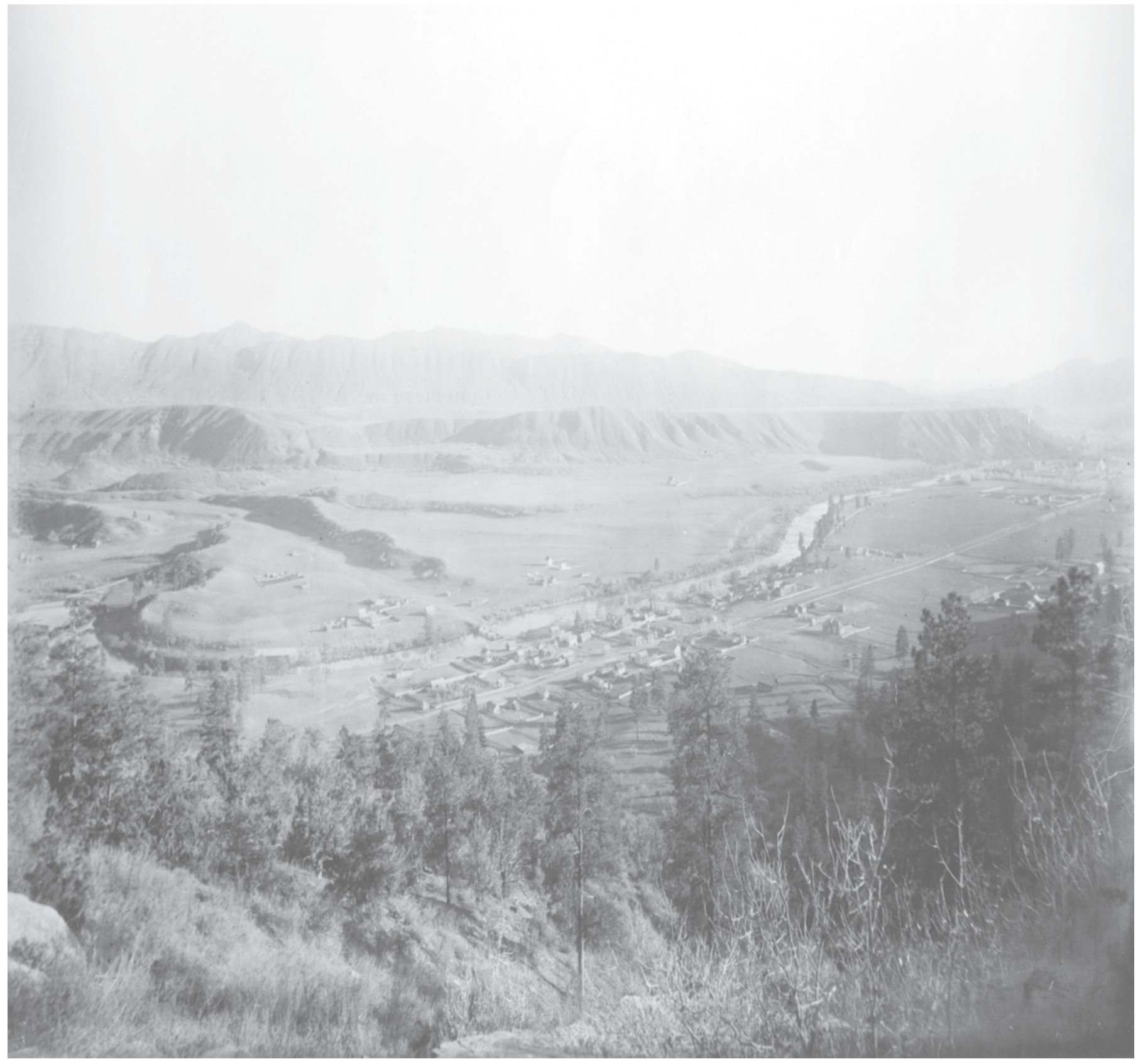




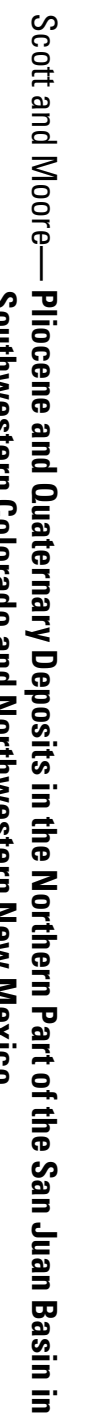

